\title{
Re: A Meta-Analysis of the Clinical Use of Curcumin for Irritable Bowel Syndrome
}

\author{
Laura Appleton $(\mathbb{1}$ and Andrew S. Day *(1) \\ Department of Paediatrics, University of Otago Christchurch, 8140 Christchurch, New Zealand; \\ laura.appleton@otago.ac.nz \\ * Correspondence: andrew.day@otago.ac.nz; Tel.: +64-3-3726718; Fax: +64-3-3640919
}

Received: 26 October 2019; Accepted: 28 October 2019; Published: 6 November 2019

We read with interest the article by $\mathrm{Ng}$ et al. [1] on the use of curcumin in irritable bowel syndrome (IBS). This work systematically reviewed five randomised-controlled trials, and included three for meta-analysis (a total of 326 subjects). The authors concluded that while safe, well tolerated, and beneficial in reducing IBS symptoms, these results were not statistically significant based on the limited evidence available.

IBS is a complex, functional gastrointestinal disorder typically characterized by chronic abdominal pain, altered bowel habit, and abdominal bloat [2]. Despite being one of the most common GI disorders, the underlying pathophysiology remains unclear. Traditionally, the aetiology of IBS has focused on altered gut motility, brain-gut interactions, visceral hypersensitivity, and psychosocial distress [3]. More recent evidence implicates a range of other factors including changes to gut immune activation, intestinal permeability, alterations in faecal flora, and bacterial dysbiosis [4,5]. The latter two factors are particularly evident in the development of post-infectious IBS [6]. Studies have also highlighted the persistence of low-grade mucosal inflammation at the microscopic and molecular level in patients with IBS, with increased recruitment of enteroendocrine cells [7].

Reflecting the various aetiologic factors and the varied clinical presentations (for example, diarrhoea predominant versus constipation predominant IBS), many management options have been considered for IBS. One recent advance in management of IBS has been the use of a diet low in fermentable oligo-, di-, monosaccharides, and Polyols (FODMAPs), which can lead to improvement in symptoms [8-11]. However, this dietary intervention is not universally beneficial. Further, given the lack of definitive therapies for IBS, there is much interest in new possible interventions.

Curcumin, derived from turmeric root (Curcuma longa), is known to have numerous actions within the body, including anti-inflammatory, antitumor, and antioxidant effects [12-20]. It is believed to modulate cell signalling molecules such as pro-inflammatory cytokines, apoptotic proteins, C-reactive protein, and also inhibits the nuclear factor (NF)- $\mathrm{KB}$ intracellular signal transduction pathway [21].

Curcumin has been investigated for numerous human ailments such as arthritis, Alzheimer's, inflammatory bowel disease, and cancer [22-31]. However, low bioavailability due to poor absorption, rapid metabolism, and rapid systemic elimination potentially limit its therapeutic efficacy [32] requiring either high doses or the need for adjuvants or additives. By way of example, the absorption of curcumin is increased by up to $2000 \%$ when combined with piperine [33].

Whilst this meta-analysis did not find curcumin to have a statistically significant effect on reducing IBS symptoms, the included studies varied widely, with likely implications on the findings arising [1]. For example, a variety of doses were seen in the included studies; ranging from 200 to $8000 \mathrm{mg}$ daily, for periods of 3 weeks to 6 months.

Since the publication of the meta-analysis, there has been one further report evaluating curcumin in patients with IBS [34]. This open-label pilot study evaluated the use of curcumin in combination with fennel oil for two months in patients with IBS seen in a primary health care setting in Belgium. 
The results of this work indicated improved quality of life and reduced symptoms following treatment. Although this study was a real-life study and included 211 subjects, it did not include a randomised placebo-controlled arm.

In conclusion, while curcumin appears to have potential clinical benefits, especially in the setting of IBS, the definitive role of this intervention is not confirmed. As highlighted by the authors of the meta-analysis, further studies are required. These should be based upon a clear consensus for a consistent therapeutic dose and dosing regimen, whether that be via optimisation of the daily dose or by using an adjuvant to increase bioavailability of curcumin.

Acknowledgments: No specific funding for this manuscript.

Conflicts of Interest: The authors declare no conflict of interest.

\section{References}

1. Ng, Q.X.; Soh, A.Y.S.; Loke, W.; Venkatanarayanan, N.; Lim, D.Y.; Yeo, W.S. A Meta-Analysis of the Clinical Use of Curcumin for Irritable Bowel Syndrome (IBS). J. Clin. Med. 2018, 7, 298. [CrossRef] [PubMed]

2. Whorwell, P.J. IBS in 2014: Developments in pathophysiology, diagnosis and management. Nat. Rev. Gastroenterol. Hepatol. 2015, 12, 72-74. [CrossRef] [PubMed]

3. Enck, P.; Aziz, Q.; Barbara, G.; Farmer, A.D.; Fukudo, S.; Mayer, E.A.; Niesler, B.; Quigley, E.M.; Rajilic-Stojanovic, M.; Schemann, M.; et al. Irritable bowel syndrome. Nat. Rev. Dis Primers. 2016, 2, 16014. [CrossRef] [PubMed]

4. Dupont, H.L. Review article: Evidence for the role of gut microbiota in irritable bowel syndrome and its potential influence on therapeutic targets. Aliment. Pharmacol. Ther. 2014, 39, 1033-1042. [CrossRef]

5. Simren, M.; Barbara, G.; Flint, H.J.; Spiegel, B.M.; Spiller, R.C.; Vanner, S.; Verdu, E.F.; Whorwell, P.J.; Zoetendal, E.G. Intestinal microbiota in functional bowel disorders: A Rome foundation report. Gut 2013, 62, 159-176. [CrossRef]

6. Spiller, R. Significance of Postinfectious Irritable Bowel Syndrome? Gastroenterology 2019, 156, 14-17. [CrossRef]

7. Ng, Q.X.; Soh, A.Y.S.; Loke, W.; Lim, D.Y.; Yeo, W.S. The role of inflammation in irritable bowel syndrome (IBS). J. Inflamm. Res. 2018, 11, 345-349. [CrossRef]

8. De Roest, R.H.; Dobbs, B.R.; Chapman, B.A.; Batman, B.; O’Brien, L.A.; Leeper, J.A.; Hebblethwaite, C.R.; Gearry, R.B. The low FODMAP diet improves gastrointestinal symptoms in patients with irritable bowel syndrome: A prospective study. Int. J. Clin. Pract. 2013, 67, 895-903. [CrossRef]

9. Halmos, E.P.; Power, V.A.; Shepherd, S.J.; Gibson, P.R.; Muir, J.G. A diet low in FODMAPs reduces symptoms of irritable bowel syndrome. Gastroenterology 2014, 146, 67-75 e5. [CrossRef]

10. Lovell, R.M.; Ford, A.C. Global prevalence of and risk factors for irritable bowel syndrome: A meta-analysis. Clin. Gastroenterol. Hepatol. 2012, 10, 712-721. [CrossRef]

11. Staudacher, H.M.; Whelan, K.; Irving, P.M.; Lomer, M.C. Comparison of symptom response following advice for a diet low in fermentable carbohydrates (FODMAPs) versus standard dietary advice in patients with irritable bowel syndrome. J. Hum. Nutr. Diet. 2011, 24, 487-495. [CrossRef] [PubMed]

12. Bachmeier, B.E.; Killian, P.; Pfeffer, U.; Nerlich, A.G. Novel aspects for the application of Curcumin in chemoprevention of various cancers. Front. Biosci. 2010, 2, 697-717. [CrossRef]

13. Biswas, S.K.; McClure, D.; Jimenez, L.A.; Megson, I.L.; Rahman, I. Curcumin induces glutathione biosynthesis and inhibits NF-kappaB activation and interleukin-8 release in alveolar epithelial cells: Mechanism of free radical scavenging activity. Antioxid. Redox Signal. 2005, 7, 32-41. [CrossRef] [PubMed]

14. Clark, C.A.; McEachern, M.D.; Shah, S.H.; Rong, Y.; Rong, X.; Smelley, C.L.; Caldito, G.C.; Abreo, F.W.; Nathan, C.O. Curcumin inhibits carcinogen and nicotine-induced Mammalian target of rapamycin pathway activation in head and neck squamous cell carcinoma. Cancer Prev. Res. 2010, 3, 1586-1595. [CrossRef]

15. Jacob, A.; Wu, R.; Zhou, M.; Wang, P. Mechanism of the Anti-inflammatory Effect of Curcumin: PPAR-gamma Activation. PPAR Res. 2007, 2007, 89369. [CrossRef]

16. Messner, D.J.; Robinson, T.; Kowdley, K.V. Curcumin and Turmeric Modulate the Tumor-Promoting Effects of Iron In Vitro. Nutr. Cancer 2017, 69, 481-489. [CrossRef] 
17. Motterlini, R.; Foresti, R.; Bassi, R.; Green, C.J. Curcumin, an antioxidant and anti-inflammatory agent, induces heme oxygenase- 1 and protects endothelial cells against oxidative stress. Free Radic. Biol. Med. 2000, 28, 1303-1312. [CrossRef]

18. Sajithlal, G.B.; Chithra, P.; Chandrakasan, G. Effect of curcumin on the advanced glycation and cross-linking of collagen in diabetic rats. Biochem. Pharmacol. 1998, 56, 1607-1614. [CrossRef]

19. Sikora, E.; Scapagnini, G.; Barbagallo, M. Curcumin, inflammation, ageing and age-related diseases. Immun. Ageing 2010, 7, 1. [CrossRef]

20. Surh, Y.J.; Han, S.S.; Keum, Y.S.; Seo, H.J.; Lee, S.S. Inhibitory effects of curcumin and capsaicin on phorbol ester-induced activation of eukaryotic transcription factors, NF-kappaB and AP-1. Biofactors 2000, 12, 107-112. [CrossRef]

21. Olivera, A.; Moore, T.W.; Hu, F.; Brown, A.P.; Sun, A.; Liotta, D.C.; Snyder, J.P.; Yoon, Y.; Shim, H.; Marcus, A.I.; et al. Inhibition of the NF-kappaB signaling pathway by the curcumin analog, 3,5-Bis(2-pyridinylmethylidene)-4-piperidone (EF31): Anti-inflammatory and anti-cancer properties. Int. Immunopharmacol. 2012, 12, 368-377. [CrossRef] [PubMed]

22. Daily, J.W.; Yang, M.; Park, S. Efficacy of Turmeric Extracts and Curcumin for Alleviating the Symptoms of Joint Arthritis: A Systematic Review and Meta-Analysis of Randomized Clinical Trials. J. Med. Food 2016, 19, 717-729. [CrossRef] [PubMed]

23. Epstein, J.; Docena, G.; MacDonald, T.T.; Sanderson, I.R. Curcumin suppresses p38 mitogen-activated protein kinase activation, reduces IL-1beta and matrix metalloproteinase- 3 and enhances IL-10 in the mucosa of children and adults with inflammatory bowel disease. Br. J. Nutr. 2010, 103, 824-832. [CrossRef] [PubMed]

24. Hanai, H.; Iida, T.; Takeuchi, K.; Watanabe, F.; Maruyama, Y.; Andoh, A.; Tsujikawa, T.; Fujiyama, Y.; Mitsuyama, K.; Sata, M.; et al. Curcumin maintenance therapy for ulcerative colitis: Randomized, multicenter, double-blind, placebo-controlled trial. Clin. Gastroenterol. Hepatol. 2006, 4, 1502-1506. [CrossRef] [PubMed]

25. Lang, A.; Salomon, N.; Wu, J.C.; Kopylov, U.; Lahat, A.; Har-Noy, O.; Ching, J.Y.L.; Cheong, P.K.; Avidan, B.; Gamus, D.; et al. Curcumin in Combination with Mesalamine Induces Remission in Patients With Mild-to-Moderate Ulcerative Colitis in a Randomized Controlled Trial. Clin. Gastroenterol. Hepatol. 2015, 13, 1444-1449. [CrossRef] [PubMed]

26. Lee, M.; Choi, H.; Kim, K.S.; Kim, D.H.; Kim, C.H.; Lee, Y.C. Curcumin Downregulates Human GM3 Synthase (hST3Gal V) Gene Expression with Autophagy Induction in Human Colon Carcinoma HCT116 Cells. Evid. Based Complement. Alternat. Med. 2018, 2018, 6746412. [CrossRef]

27. Tang, M.; Taghibiglou, C. The Mechanisms of Action of Curcumin in Alzheimer's Disease. J. Alzheimers Dis. 2017, 58, 1003-1016. [CrossRef]

28. Wang, Y.; Tang, Q.; Duan, P.; Yang, L. Curcumin as a therapeutic agent for blocking NF-kappaB activation in ulcerative colitis. Immunopharmacol. Immunotoxicol. 2018, 40, 476-482. [CrossRef]

29. Zhang, L.; Fang, Y.; Cheng, X.; Lian, Y.J.; Xu, H.L.; Zeng, Z.S.; Zhu, H.C. Curcumin Exerts Effects on the Pathophysiology of Alzheimer's Disease by Regulating PI(3,5)P2 and Transient Receptor Potential Mucolipin-1 Expression. Front. Neurol. 2017, 8, 531. [CrossRef]

30. Zhang, Y.; Kong, Y.; Liu, S.; Zeng, L.; Wan, L.; Zhang, Z. Curcumin induces apoptosis in human leukemic cell lines through an IFIT2-dependent pathway. Cancer Biol. Ther. 2017, 18, 43-50. [CrossRef]

31. Zhu, W.T.; Liu, S.Y.; Wu, L.; Xu, H.L.; Wang, J.; Ni, G.X.; Zeng, Q.-B. Delivery of curcumin by directed self-assembled micelles enhances therapeutic treatment of non-small-cell lung cancer. Int. J. Nanomed. 2017, 12, 2621-2634. [CrossRef] [PubMed]

32. Metzler, M.; Pfeiffer, E.; Schulz, S.I.; Dempe, J.S. Curcumin uptake and metabolism. Biofactors 2013, 39, 14-20. [CrossRef] [PubMed]

33. Shoba, G.; Joy, D.; Joseph, T.; Majeed, M.; Rajendran, R.; Srinivas, P.S. Influence of piperine on the pharmacokinetics of curcumin in animals and human volunteers. Planta Med. 1998, 64, 353-356. [CrossRef] [PubMed]

34. Di Ciaula, A.; Portincasa, P.; Maes, N.; Albert, A. Efficacy of bio-optimized extracts of turmeric and essential fennel oil on the quality of life in patients with irritable bowel syndrome. Ann. Gastroenterol. 2018, 31, 685-691. [CrossRef]

(C) 2019 by the authors. Licensee MDPI, Basel, Switzerland. This article is an open access article distributed under the terms and conditions of the Creative Commons Attribution (CC BY) license (http://creativecommons.org/licenses/by/4.0/). 